\title{
Progress on nutritional requirements of deer farmed for velvet production in China
}

\author{
GAO XIUHUA ${ }^{1}$, YANG FUHE ${ }^{2}$, LI CHUNYI ${ }^{3}$ and D.R. STEVENS ${ }^{3}$ \\ ${ }^{1}$ Institute of Feed Research CAAS, Beijing, 100081, P.R. China \\ ${ }^{2}$ Institute of Special Wild-Economic Animal and Plant Sciences CAAS, Jilin 132109, P.R. China \\ ${ }^{3}$ AgResearch Invermay Agricultural Centre, Private Bag 50034, Mosgiel, New Zealand \\ gxh@challenge.com.cn
}

\begin{abstract}
Research in China has shown a marked variation in the energy and protein requirements of sika deer (Cervus nippon) for velvet antler production as the stag grows. Information includes energy and protein requirements for male sika deer throughout their life and pregnant and lactating females. Estimates of energy utilization and methane production are also included. Protein requirements during early growth and development of the stag are high, while they decline as the stag ages. Protein requirements during velvet antler growth are higher than during other times of year. The maintenance energy requirements of the male sika deer of 0.52 MJME/ $\mathrm{kgBW}^{0.75}$ are similar to those estimated for red deer. The Chinese system of reporting gross energy, digestible energy and digestible protein requirements has been converted into metabolisable energy requirements and diet protein concentrations for the New Zealand feeding system to aid interpretation.
\end{abstract}

Keyw ords: Cervus nippon, deer, energy, feed requirements, methane, protein, sika, velvet antler

\section{Introduction}

Deer are animals which have very high economic value. Deer farming in China can be traced back 300 years. Chinese fam deer mainly to produce velvet antler. Velvet antler is a valuable traditional medicine that is widely used in most Asian countries. The species of deer used for velvet production in China are sika deer (Cervus nippon) and wapiti (C. elaphus).

In recent years, due to high economic returns from velvet antler and deer co-products, deer farming has been rapidly expanding not only in China and some Asian countries, but also in non-traditional countries, like New Zealand, Australia and Canada.

Today, world deer farming has become a developed industry. In order to meet the demand of this fast expanding industry, a series of studies has been carried out on how to make use of available feed sources rationally, reduce feed costs and fully sa tisfy the needs of antler-producing stags for a variety of nutrients.

Data for the nutritional requirements of velvet antler production is summarized here from Chinese research. It is a comprehensive series of investigations into the changing requirements of the male sika deer from weaning until maturity and adds significantly to what is known in New Zealand. However, the Chinese and New Zealand systems for describing energy and protein requirements are different. Care should be taken to distinguish between these systems and that the feeding levels are not directly transferred to New Zealand situations without proper interpretation. Some attempt has been made to aid that inter pretation in Table 1, and the final section of the paper.

\section{Deer farming in China}

Deer farms were initially located in the natural habitat of the sika and wapiti deer in the northeast of China. In recent years, with the increase in demand for velvet antler as a traditional medicine, deer farms have been built up all over China, spreading from the northeast. Recent statistics report that China now has at least 1.1 million farmed deer, up from 500,000 in the early 1990's. Dried velvet antler production is around 500 tons per annum (approximately $1500 \mathrm{t}$ green weight).

The two main species of farmed deer in China are sika deer and wapiti, though China is home to at least a dozen deer species. Currently, sika deer accounts for $84 \%$ of the deer population, wapiti accounts for $13 \%$, and the rest of the deer species constitute $3 \%$.

The Chinese farm deer in feed lots rather than at pasture due to the pressure on land for other uses. Diets are made up of concentrates with supplementary roughage in the form of leaves, branches and cut forage.

\section{Energy Metabolism}

Recent studies have established the metabolic requirements for sika deer. Gao et al. (1996a) conducted feeding trials, digestion trials and respiratory heat measurement tests to investigate energy metabolism for adult male deer (mature size of 120-140 kg). Results indicated that fasting heat production requirements were $365 \mathrm{KJ} / \mathrm{kgW}^{0.75}$ and metabolisable energy for maintenance was $516 \mathrm{KJ} / \mathrm{kgW}^{0.75}$, with energy being used with an efficiency of 0.707 for maintenance. Gao et al. (1996a) also carried out heat of respiration trials and digestion-metabolism trials at different feeding levels using 4 male deer. Results showed that energy digestibility, metabolic rate, heat production and body energy retention were all raised when gross energy intake 
increased. Energy reserves might be deposited with efficiencies of 0.59 and 0.61 for protein and fat, respectively.

The metabolic production of methane energy $\left(\mathrm{CH}_{4} \mathrm{E}\right)$ of sika deer was studied using indirect respiration calorimetry and digestion-metabolism trials in adult male sika deer (Li et al. 1996). Results showed that the amount of $\mathrm{CH}_{4} \mathrm{E}$ produced from sika deer was raised as feed intake increased and fell with the lapse of time after feeding. The amount of $\mathrm{CH}_{4} \mathrm{E}$ produced was $6.6 \%, 8.8$ $\%$ and $10.9 \%$ of gross energy intake (GEI), digestible energy intake and retained energy, respectively. In addition, $\mathrm{CH}_{4} \mathrm{E}$ production was decreased following improvement of the dietary protein level. When the dietary protein level was increased by $1 \%$, the amounts of $\mathrm{CH}_{4} \mathrm{E}$ production was reduced by $58.6 \mathrm{~kJ}$ per day. The relationships between $\mathrm{CH}_{4} \mathrm{E}$ and gross energy intake and dry matter intake (DMI) were expressed by the following equations:

$\mathrm{CH}_{4} \mathrm{E}(\mathrm{kJ} / \mathrm{d})=0.07 \mathrm{GEI}(\mathrm{kJ} / \mathrm{d})-101.04$

$\mathrm{CH}_{4} \mathrm{E}(\mathrm{kJ} / \mathrm{d})=98.78+1.05 \mathrm{DMI}(\mathrm{g} / \mathrm{d})$

\section{Optimal Dietary Nutritional Levels and Requirements}

\section{Post-weaning period (body weight of 30-60 kg)}

Wang et al. (1996) studied the effects of different energy and protein levels on young deer after weaning. Results indicated that the optimal gross energy (GE) and protein (CP) levels in concentrated feed were 17.2-18.0 MJ/kg and $28 \%$ r espectively. Total daily digestible crude protein (DCP) requirement was $219-232 \mathrm{~g} / \mathrm{d}$ and digestible energy (DE) requirement was 23.4-24.6 MJ/d (Gao et al. 1996).

\section{Growth Stage (body weight of 60-100 $\mathrm{kg}$ )}

Gao et al. (1997) showed that live weight gains of the yearling sika deer were significantly influenced by the interaction between dietary energy and protein. The apparent digestibility of crude protein was increased following the increase in dietary protein level. The optimal dietary energy and crude protein concentrations were 17.4 MJ GE/kg and $22.4 \% \mathrm{CP}$ respectively. The daily requirements of energy and protein per deer were 28.5-28.9 MJ DE/d and 400-410 g DCP/d respectively during the antler growth period for y earling sika deer. Gao \& Wang (1996) investigated the effects of dietary protein and energy levels on weight gain for yearling sika deer in winter. Results indicated that the optimal protein level was $18 \% \mathrm{CP}$, energy concentration was 16.3 MJ GE/kg in the supplemental concentrate, and the daily requirements of protein and energy per deer were $150 \mathrm{~g} \mathrm{DCP}$ and 23.1 MJ DE respectively.

Gao et al. (1993) studied the effects of different levels of dietary protein and energy on the velvet antler yield and weight during the antler growth period for two- year-old male sika deer. The results indicated that the intakes of crude protein and digestible crude protein per day were significantly influenced by dietary protein level. The CP and DCP intakes were higher for the groups receiving $21 \% \mathrm{CP}$ than for those receiving $18 \% \mathrm{CP}$. There was no significant difference between the different groups in velvet antler yield. The live weight gains of the group fed $21 \% \mathrm{CP}$ were numerically higher than those fed $18 \% \mathrm{CP}$, but there were no statistically significant differences between them. The energy level had no significant effects on the velvet antler yield and weight gain. These did not increase with the increased energy concentration in the diets. The results of these experiments demonstrated that the optimal crude protein, energy concentration and protein-energy ratio were 18.519.5\% CP, 16.5-17.0 MJ GE/kg and 12-13 g/MJ respectively. The total daily requirements of dig estible crude protein and digestible energy were $315 \mathrm{~g} \mathrm{DCP} / \mathrm{d}$ and 27.2-29.9 MJ DE/d respectively.

Gao et al. (1995) measured the energy and protein requirements in feeding and digestion trials for two-yearold deer in winter. They suggested that DE requirement was $36.9 \mathrm{MJ} / \mathrm{d}$ and DCP requirement was $194 \mathrm{~g} / \mathrm{d}$.

There has been little research conducted on the mineral nutrition of deer. Wang et al. (1997) conducted a study to investigate the effects of dietary $\mathrm{Ca}$ and $\mathrm{P}$ levels on antler growth using 3-year-old sika deer. Results sho wed that the optimal $\mathrm{Ca}$ and $\mathrm{P}$ levels in the diet were $0.89 \%$ and $0.52 \%$ respectively. $\mathrm{Ca}$ and $\mathrm{P}$ levels in the diet had effects on $\mathrm{Ca}$ contents in antler serum at the antlerharvesting stage, but no effects on P contents.

\section{Adult male Sika Deer (mature body weight of 100- $140 \mathrm{~kg}$ )}

In the past ten years, Jin and Gao et al. have investigated the protein and energy requirements for adult sika deer (over four years old) in feeding and digestion trials. Results showed that the optimal dietary energy concentration and crude protein levels were 16.7-17.2 MJ GE/kg and 16 to $18 \% \mathrm{CP}$ respectively. The total daily requirements of digestible crude protein and digestible energy were 330-360 g DCP/d and 38.1-39.8 $\mathrm{MJ} \mathrm{DE} / \mathrm{d}$ respectively during the antler growth period. In winter, the total daily protein requirement was 200$230 \mathrm{~g} \mathrm{DCP} / \mathrm{d}$ and the energy requirement was 33.1-37.7 $\mathrm{MJ}$ DE/d.

\section{Adult female Sika Deer (mature body weight of 80- $95 \mathrm{~kg}$ )}

A few studies have been undertaken to estimate the optimal dietary energy concentration and crude protein level for female sika deer during different physiological periods using feeding and digestion trials (Gao et al. 1996b).

Results during gestation showed that the optimal energy concentration and crude protein level in 


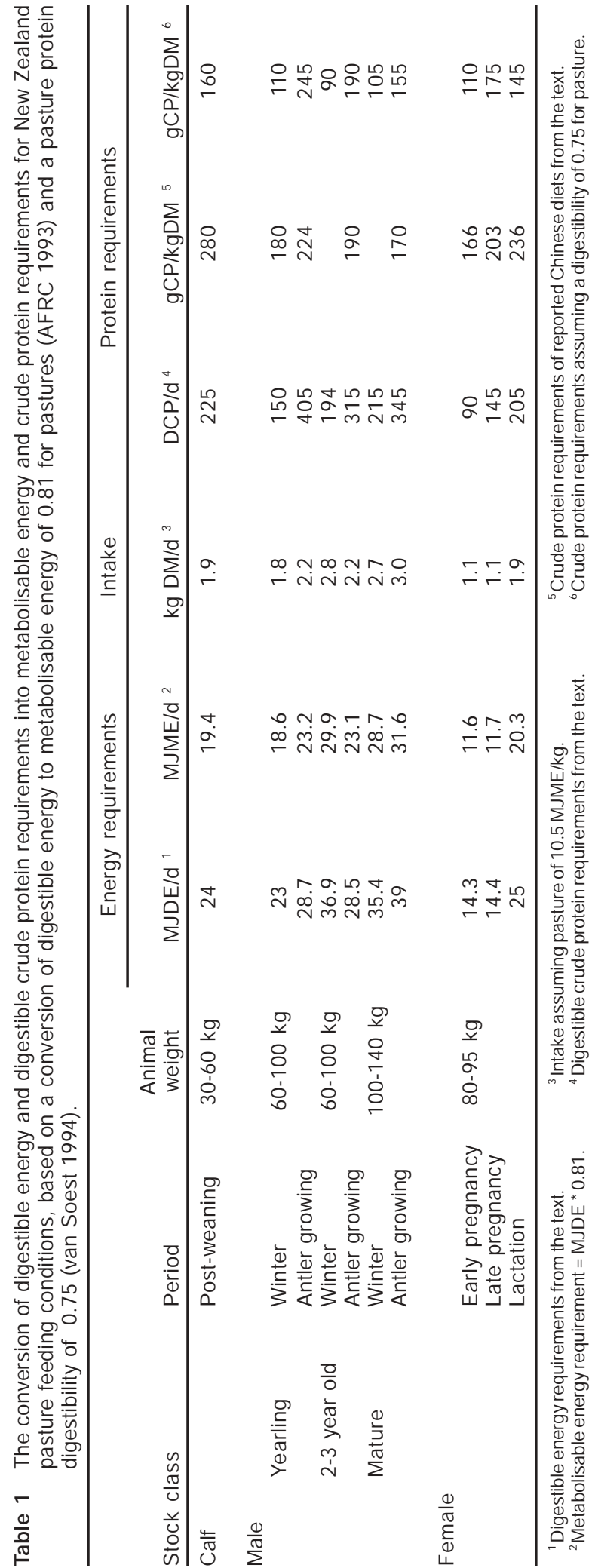

concentrated feed were 16.7 MJ GE/kg and $16.6 \%$ $\mathrm{CP}$ respectively in mid pregnancy. The optimal energy concentration and crude protein level in concentrated feed were $17.1 \mathrm{MJ} \mathrm{GE} / \mathrm{kg}$ and $20.3 \%$ $\mathrm{CP}$ respectively during late pregnancy. The daily requirements of digestible energy and digestible crude protein per deer were 14.4 MJ DE/d and 85$90 \mathrm{~g} \mathrm{DCP} / \mathrm{d}$ respectively during mid pregnancy. The daily requirements of digestible energy and digestible crude protein during late pregnancy were 14.4 MJ DE/d and 140-145 g DCP/d respectively for female sika deer.

Feeding and digestion trials were conducted with female sika deer during lactation. The results showed that dietary energy concentration had significant effects on the suckling calf body weight gain, protein digestibility and energy digestibility $(\mathrm{P}<0.01)$. The optimal energy concentration and crude protein level in concentrated feed were 17.6 $\mathrm{MJ} \mathrm{GE} / \mathrm{kg}$ and $23.6 \% \mathrm{CP}$ respectively. The daily requirements of digestible energy and digestible crude protein per deer were 24-25 MJ DE/d and 200-210 g DCP/d respectively during the lactation period for female sika deer (Gao et al. 2001).

The requirements of dietary crude protein for female wapiti (Chinese Malu) were determined in digestion and metabolism experiments. The appropriate levels of dietary crude protein for the gestation and lactation periods were approximately $10 \%$ and $15 \%$ CP respectively (Li et al. 2000).

\section{Implications for New Zealand farming systems}

Experiences with feeding in China can be made relevant to New Zealand deer farming through the conversion of the requirements outlined in the text to the New Zealand forage system. The New Zealand system is based on metabolisable energy (ME). Table 1 converts the text values for digestible energy (DE) requirements to metabolisable energy requirements using a generalized relationship of ME/DE of 0.81 (AFRC 1993). Dry matter intake is then calculated based on an energy concentration in pasture of $10.5 \mathrm{MJME} / \mathrm{kgDM}$.

Daily digestible crude protein requirements from the text have also been converted into dietary crude protein concentrations based on the daily feed intake and a general digestibility of crude protein in pasture of $75 \%$ (van Soest 1994). Of interest is the high protein requirement for stags during the early years of antler development. Research in New Zealand (Suttie unpub. data) showed small increases in antler weight and significant increases in antler quality associated with high protein supplements. 
The estimated New Zealand dietary CP concentrations are at times different from the dietary protein concentrations of the Chinese diets (Table 1). Generally the predicted dietary protein concentrations for deer grazing New Zealand pastures are lower than those suggested by the Chinese research. This may be due to the different species of deer or the feeds available.

Diets formulated in China rely on byproducts from human food industries, as well as supplementation using forages of many sources. The New Zealand pasture diet is relatively constant by comparison. An illustration of the complexity of Chinese diets comes from the number of feeds available. Yang et al. (1994) conducted nutritional composition analysis for 110 kinds of feedstuff and reported the values for the dry matter, energy, crude protein, crude lipids, crude fibre, nitrogen free extracts and crude ash of the different kinds of feed. These feeds included concentrates (loose mix of cereal grains), meals (feed cakes made from the residue after oilseed extraction), sorghum and wheat bran (seed coats left after flour extraction), dry tree leaves, fresh grass, byproducts from agriculture, by-products from industries, and animal derived feed. Li et al. (1996) analysed the nutritional composition of 42 kinds of tree leaves and 51 fresh grasses using multiple-cluster statistical methods and found that tree leaves could be divided into 3 to 4 categories; fresh grasses could be divided into 7 categories.

These feeds vary widely in digestibility. Jin et al. (1994) measured the degradation rate for dry matter, protein, and organic matter of corn, fresh oak tree leaves, corn silage, wheat bran, soybean cake and soybean residue. Gao et al. (1996) measured the degradation rate for dry matter, protein, and organic matter for 73 kinds of deer feed. Degradation rates of $0.0339 / \mathrm{h}, 0.0266 / \mathrm{h}$, $0.0244 / \mathrm{h}$ and $0.0213 / \mathrm{h}$ for soybean cake, corn powder, oak leaves and corn silage were measured respectively when their particle size was approximately $0.25-0.50$ $\mathrm{mm}$.

Dried and processed feeds also vary significantly in the digestibility of protein while the protein in fresh pasture has a very high digestibility (van Soest 1994). This has significant impacts on the crude protein concentrations needed in the diet to meet animal requirements.

\section{Conclusions}

Research in China has provided a wealth of nutrition information to help advance the Chinese velvet antler industry. Lessons from the Chinese research in diet formulation and protein requirements may provide some future direction for the improvement of the New Zealand velvet antler industry when interpreted and tested in New Zealand conditions.

\section{REFERENCES}

AFRC, 1993. Energy and protein requirements of ruminants. An advisory manual prepared by the AFRC Technical Committee on Responses to Nutrients. CAB International, Wallingford, UK.

Gao Xiuhua; Jin Shundan; Yang Fuhe; Jin Dezhe. 1997. Effects of different levels of dietary energy and protein on the yearling sika deer during the antler growth period. Journal of Economic Animal. 1(1): 20-25.

Gao Xiuhua; Jin Shundan; Yang Fuhe; Wang Feng. 1993. Effects of different levels of dietary protein and energy on the antler yield and weight during the antler growth period for two-year male sika deer. Acta Zoonutrimenta Sinica. 5(2): 43-47.

Gao Xiuhua; Wang Feng. 1996. The optimal energy and protein levels in concentrate for yearling sika deer in winter. Special Wild Economic Animal and Plant Research. 2: 25-27.

Gao Xiuhua; Yang Fuhe; Cao Jiayin; Jin Shundan. 1995. The optimal energy and protein levels in concentrate for two-year male sika deer in winter. Special Wild Economic Animal and Plant Research. 3: $15-21$.

Gao Xiuhua; Yang Fuhe; Jin Shundan. 1996b. Recent development in requirements of energy and protein in sika deer. Animal Nutrition Research Proceeding. 59-61.

Gao Xiuhua; Zhang Xiaoming; Yang Fuhe; Jin Shundan. 1996a. Energy requirements for maintenance in adult sika deer. Acta Zoonutrimenta Sinica. 8(1): 52-55.

Li Zhongkuan; Gao Xiuhua; Yang Fuhe; Jin Shundan. 1996. Studies on the metabolic rule of methane energy $\left(\mathrm{CH}_{4} \mathrm{E}\right)$ of sika deer. Acta Theriologica Sinica. 16(2): 100-104.

van Soest, P.J. 1994. Nutritional Ecology of the Ruminant. Cornell University Press, Ithica, NY. 476pp.

Wang Feng; Gao Xiuhua; Jin Shundan. 1997. Studies on the optimal $\mathrm{Ca}$ and $\mathrm{P}$ levels in diet at the antler growing sta ge in 3-year old sika deer. Acta Zoonutrimenta Sinica. 9(1): 35-38.

Wang Feng; Gao Xiuhua; Jin Shundan; Yang Fuhe. 1996. Study on adequate energy density and protein level of concentrated feed in young sika deer. '96 International Symposium on Deer Science and Deer Products. 123: 124. 